\title{
Impact of Grazing Intensity and Seasons on Greenhouse Gas Emissions in Tropical Grassland
}

\author{
Abmael da Silva Cardoso $\odot,{ }^{1,3 *}$ Liziane de Figueiredo Brito, ${ }^{1}$ Estella Rosseto \\ Janusckiewicz, ${ }^{1}$ Eliane da Silva Morgado, ${ }^{2}$ Rondineli Pavezzi Barbero $\odot,{ }^{1}$ \\ Jefferson Fabiano Werner Koscheck, ${ }^{1}$ Ricardo Andrade Reis, ${ }^{1}$ and Ana \\ Cláudia Ruggieri ${ }^{1}$
}

\begin{abstract}
${ }^{1}$ Departamento de Zootecnia, Faculdade de Ciências Agrárias e Veterinárias, UNESP - Univ Estadual Paulista, 14884-900 Jaboticabal, SP, Brazil; ${ }^{2}$ Uberlandia Federal University, Rua João Naves de Ávila 2121, Santa Mônica, 38408-100 Uberlândia, MG, Brazil; ${ }^{3}$ Universidade Estadual Paulista Julio de Mesquita Filho Via de Acesso Prof Paulo Donato Castellane UNESP, Sao Paulo, Sao Paulo 01049-010, Brazil
\end{abstract}

\begin{abstract}
Greenhouse gases (GHG) can be affected by grazing intensity, soil, and climate variables. This study aimed at assessing GHG emissions from a tropical pasture of Brazil to evaluate (i) how the grazing intensity affects the magnitude of GHG emissions; (ii) how season influences GHG production and consumption; and (iii) what are the key driving variables associated with GHG emissions. We measured under field conditions, during two years in a palisade-grass pasture managed with 3 grazing intensities: heavy $(15 \mathrm{~cm}$ height), moderate $(25 \mathrm{~cm}$ height), and light (35 cm height) $\mathrm{N}_{2} \mathrm{O}, \mathrm{CH}_{4}$ and $\mathrm{CO}_{2}$ fluxes using static closed chambers and chromatographic quantification. The greater emissions occurred in the summer and the lower in the winter. $\mathrm{N}_{2} \mathrm{O}, \mathrm{CH}_{4}$, and $\mathrm{CO}_{2}$ fluxes varied according
\end{abstract}

to the season and were correlated with pasture grazing intensity, temperature, precipitation, \% WFPS (water-filled pores space), and soil inorganic $\mathrm{N}$. The explanatory variables differ according to the gas and season. Grazing intensity had a negative linear effect on annual cumulative $\mathrm{N}_{2} \mathrm{O}$ emissions and a positive linear effect on annual cumulative $\mathrm{CO}_{2}$ emissions. Grazing intensity, season, and year affected $\mathrm{N}_{2} \mathrm{O}, \mathrm{CH}_{4}$, and $\mathrm{CO}_{2}$ emissions. Tropical grassland can be a large sink of $\mathrm{N}_{2} \mathrm{O}$ and $\mathrm{CH}_{4}$. GHG emissions were explained for different key driving variables according to the season.

Key words: grassland management; grazing height; $\mathrm{CH}_{4}$ from grassland soil; soil respiration; water-filled pore space; nitrous oxide.
Received 10 May 2016; accepted 3 September 2016; published online 7 December 2016

Author contributions The authors LFB, RAR and ACR conceived and designed the study; ASC, LFB, ERJ, ESM, RPB and JFWK performed research; ASC analysed the data and, ASC, LFB, ERJ and ACR wrote the paper

*Corresponding author; e-mail: abmael2@gmail.com

\section{INTRODUCTION}

Livestock production accounts for $70 \%$ of all agricultural land and $30 \%$ of the land surface of the planet. The sector is responsible for $18 \%$ of global greenhouse gas emissions (GHG) measured in $\mathrm{CO}_{2}$ equivalents. It accounts for $9 \%$ of anthropogenic $\mathrm{CO}_{2}, 37 \%$ of methane $\left(\mathrm{CH}_{4}\right)$, and $65 \%$ of nitrous oxide $\left(\mathrm{N}_{2} \mathrm{O}\right)$ emissions as well as $64 \%$ of ammonia $\left(\mathrm{NH}_{3}\right)$ release, which contributes indirectly to $\mathrm{N}_{2} \mathrm{O}$ 
emissions and acidification of ecosystems (Steinfeld and others 2006). Livestock is an important sector in tropical countries.

Grassland management strategies affect animal intake, forage residue amount and quality, and pasture structure (Shariff and others 1994; Apolinário and others 2014). Nutrients from grazing areas return through the deposition of dung and urine (Haynes and Williams 1993). Different defoliation frequencies and intensities, which influence the proportions of leaf, stem, and dead material, affect $\mathrm{C}$ and $\mathrm{N}$ cycling due to their effects on the biochemical composition of residues (Liu and others 2011), N concentrations in plant tissues (Boddey and others 2004), and soil microbial population and diversity (Zhou and others 2010). We hypothesized that grazing intensity can affect $\mathrm{CO}_{2}$, $\mathrm{CH}_{4}$, and $\mathrm{N}_{2} \mathrm{O}$ emission from soil.

The edaphoclimatic characteristics of the northwestern region of the Brazilian state of São Paulo, which is the region of our research interest, are similar to those of the Cerrado biome (Miranda and Fonseca 2013). These characteristics include annual rainfall ranging between 1200 and $1600 \mathrm{~mm}$ and occurring mostly during the warm summer season (October to April), thereby contrasting with temperate and subtropical regions (Lopes 1996). It is known that high levels of precipitation and temperature result in the rapid formation of anoxic conditions in the soil, although rapid water infiltration and high evapotranspiration rates suggest that these conditions may be temporary (Skiba and Ball 2002; Lessa and others 2014). Anoxic microsites in the soil can favor $\mathrm{N}_{2} \mathrm{O}$ production (Smith and others 2003).

The winters in this Brazilian region are severely dry, frequently having more than 90 days without rain, and have a temperature range from 15 to $25^{\circ} \mathrm{C}$, conditions that do not favor $\mathrm{CH}_{4}$ and $\mathrm{N}_{2} \mathrm{O}$ production (Lessa and others 2014). The dry winter season also has a short photoperiod and low soil moisture. The low rainfall compromises grass growth, thereby leading to seasonality of grass production (de Pinho Costa and others 2006). The climatic characteristics described above led us to hypothesize that season affects GHG production and consumption in a grassland soil.

The importance of GHG emissions resulting from livestock production in tropical regions is increasing. Understanding the effects of grassland management and season on GHG production and consumption may help develop strategies to mitigate GHG. Here, we assessed GHG emissions from a tropical pasture in Brazil to determine (i) how grazing intensity (light, moderate, and heavy) af- fects the magnitude of GHG emissions; (ii) how season influences GHG production and consumption; and (iii) how the key driving variables are associated with GHG emissions.

\section{MATERIALS AND METHODS}

\section{Site Description}

The experiment was conducted at the Forages and Grasslands division of São Paulo State University "Julio de Mesquita Filho" (UNESP), in Jaboticabal, SP, Brazil $\left(21^{\circ} 15^{\prime} 22^{\prime \prime} \mathrm{S}, 48^{\circ} 18^{\prime} 58^{\prime \prime} \mathrm{W}\right)$, at an altitude of $595 \mathrm{~m}$. The local climate is tropical, with a rainy season (October to March), during which more than $80 \%$ of annual precipitation normally occurs, and a dry season (April to September). Mean annual rainfall is $1424 \mathrm{~mm}$ and mean air temperature is $22.3^{\circ} \mathrm{C}$. The soil is a Rhodic Ferralsol (IUSS 2006) derived from basalt. The pastures used in the study site were seeded in 2001 with Brachiaria brizantha (Hockst ex A. Rich) Stapf cv. Marandu (palisadegrass). Soil chemical composition and physical characteristic are presented in Table 1.

\section{Experimental Design and Grassland Management}

The cultivar of Brachiaria brizantha Marandu was realized by Embrapa (Brazilian Agricultural Research Corporation) in 1984, and studies found that the best nutritional quality and vigor of the cultivar are observed at $40-\mathrm{cm}$ plant height, whereas the minimal height that does not prejudice plant regrowth or sustentation of pasture perennials is $15 \mathrm{~cm}$ height (Euclides and others 2014). Thus, three pasture management heights were chosen, 15,25 , and $35 \mathrm{~cm}$ that consist of three grazing intensity treatments: heavy, moderate, and light, respectively, with six replications (paddocks) in a completely randomized design. Paddocks were managed under continuous stocking, with paddock areas of $0.7,1.0$, and 1.3 ha for the $15 \mathrm{~cm}$ (heavy grazing intensity), $25 \mathrm{~cm}$ (moderate grazing intensity), and $35 \mathrm{~cm}$ (light grazing intensity) pasture heights, respectively. The variation in paddock size was implemented to maintain the same number of animals per paddock. Six Nellore yearling bulls were utilized per paddock. Additional animals were used to maintain pre-determined grazing intensity, using the put-and-take methodology (Mott and Lucas 1952).

The experiment was conducted over 2 years, from $11 / 21 / 2012$ to $11 / 28 / 2014$. Maintenance fertilizer was applied to all paddocks on December 10,2012 , at a rate of $180 \mathrm{~kg} \mathrm{ha}^{-1}$ of a mixture 
Table 1. Soil Chemical Composition and Texture in the Palisade-Grass Pasture Paddocks Under Light (35 $\mathrm{cm}$ height), Moderate (25 cm height), and Heavy (15 cm height) Grazing Intensities

\begin{tabular}{|c|c|c|c|c|c|c|c|c|c|c|c|c|}
\hline \multirow[t]{2}{*}{ Treatments } & \multicolumn{8}{|c|}{ Soil chemical composition } & \multicolumn{3}{|c|}{ Soil texture $^{4}$} & \multirow{2}{*}{$\begin{array}{l}\mathrm{SBD}^{5} \\
\left(\mathrm{~g} \mathrm{~cm}^{-3}\right)\end{array}$} \\
\hline & $\mathrm{pH}^{1}$ & $\begin{array}{l}\mathrm{OM}^{2} \\
\left(\mathrm{~g} \mathrm{dm}^{-3}\right)\end{array}$ & $\begin{array}{l}\mathrm{P} \\
(\mathrm{mg} \\
\left.\mathrm{dm}^{-3}\right)\end{array}$ & $\begin{array}{l}\mathrm{K} \\
(\mathrm{mmolc} \\
\left.\mathrm{dm}^{-3}\right)\end{array}$ & $\begin{array}{l}\mathrm{Ca} \\
(\mathrm{mmolc} \\
\left.\mathrm{dm}^{-3}\right)\end{array}$ & $\begin{array}{l}\mathrm{Mg} \\
(\mathrm{mmolc} \\
\left.\mathrm{dm}^{-3}\right)\end{array}$ & $\begin{array}{l}\mathrm{H}+\mathrm{Al} \\
(\mathrm{mmolc} \\
\left.\mathrm{dm}^{-3}\right)\end{array}$ & $V^{3}(\%)$ & $\begin{array}{l}\text { Clay } \\
\left(\mathrm{g} \mathrm{kg}^{-1}\right)\end{array}$ & $\begin{array}{l}\text { Lime } \\
\left(\mathrm{g} \mathrm{kg}^{-1}\right)\end{array}$ & $\begin{array}{l}\text { Sand } \\
\left(\mathrm{g} \mathrm{kg}^{-1}\right)\end{array}$ & \\
\hline Light & 4.7 & 27 & 6 & 1.4 & 16 & 10 & 38 & 42 & 269 & 98 & 633 & 1.59 \\
\hline Moderate & 4.3 & 25 & 8 & 2.3 & 11 & 8 & 58 & 27 & 291 & 86 & 623 & 1.57 \\
\hline Heavy & 4.7 & 26 & 7 & 0.8 & 15 & 10 & 38 & 40 & 312 & 107 & 581 & 1.61 \\
\hline \multicolumn{13}{|c|}{$\begin{array}{l}{ }^{1} \text { Soil } p H \text { in } \mathrm{CaCl}_{2} . \\
{ }^{2} \text { Soil organic matter. } \\
{ }^{3} \text { Percent of base saturation. } \\
{ }^{4} \text { Soil texture was sandy-clay-loam. } \\
{ }^{5} \text { SBD-Soil bulk density. }\end{array}$} \\
\hline
\end{tabular}

containing $4 \% \quad \mathrm{~N}, 14 \% \quad \mathrm{P}_{2} \mathrm{O}_{5}$, and $8 \% \quad \mathrm{~K}_{2} \mathrm{O} . \mathrm{N}$ maintenance fertilizer was split among three applications. During the first year of the experiment, a total of $160 \mathrm{~kg} \mathrm{~N} \mathrm{ha}^{-1}$ as urea was applied according to the precipitation schedule on December 27, 2012, January 22, 2013, and February 26, 2013. During the second year, a total of $180 \mathrm{~kg} \mathrm{~N}$ $\mathrm{ha}^{-1}$ as urea was applied on November 22, 2013, January 8, 2014, and February 28, 2014.

\section{Greenhouse Gas Flux Measurements}

We used the closed static chamber technique (Mosier 1989) to collect air samples. Polyurethane vented chambers $38 \mathrm{~cm}$ in height were covered with thermal insulation mantles. Chamber headspace was $0.025 \mathrm{~m}^{3}$. Chambers were deployed on round metal bases at the beginning of each 9:0010:00 am sampling event, as suggested by Alves and others (2012). The chambers were equipped with a rubber belt to seal the chamber base and an output valve for sample removal. The linearity of gas accumulation in the chamber was successfully tested in a preliminary experiment with intensive sampling every $10 \mathrm{~min}$ for $1 \mathrm{~h}$. Air samples were taken with 50-ml polypropylene syringes. Air temperatures outside and inside of the chambers were recorded using a digital thermometer. The air sample was transferred to into 20 -ml pre-evacuated vials (Shimadzu flasks). Two sampling schemes were adopted. One for the rainy season when GHG production was favored due to rain, plant growth, higher $\mathrm{N}$ deposition, most soil moisture and higher temperatures. In this period, samples were collected 3 times a week during the rainy season (from January 10 to February 23, 2013, and from January 8 to February 26, 2014), and every 14 days during the rest of the experimental period. There were a total of 72 sampling events.
Samples were analyzed by gas chromatography (Shimadzu Greenhouse 2014) under the following conditions: (1) $\mathrm{N}_{2} \mathrm{O}$ measurement: injector at $250^{\circ} \mathrm{C}$, column at $80^{\circ} \mathrm{C}$, carrier gas was $\mathrm{N}_{2}$ $\left(30 \mathrm{ml} \mathrm{min}{ }^{-1}\right.$ ), electron capture detector at $325^{\circ} \mathrm{C}$; (2) $\mathrm{CH}_{4}$ measurement: flame gas was $\mathrm{H}_{2}$ (30 $\mathrm{ml} \mathrm{min}^{-1}$ ), flame ionization detector at $280^{\circ} \mathrm{C}$. (3) $\mathrm{CO}_{2}$ measurement: thermal conductivity detector at $250^{\circ} \mathrm{C}$.

Fluxes of $\mathrm{N}_{2} \mathrm{O}\left(\mu \mathrm{g} \mathrm{m}^{-2} \mathrm{~h}^{-1}\right), \mathrm{CH}_{4}\left(\mu \mathrm{g} \mathrm{m}^{-2} \mathrm{~h}^{-1}\right)$, and $\mathrm{CO}_{2}\left(\mathrm{mg} \mathrm{m}^{-2} \mathrm{~h}^{-1}\right)$ were calculated taking into account the linear increase of gas concentration during the incubation period, air temperature and pressure, chamber volume, and area of the metal bases (Cardoso and others 2016). Cumulative emissions $\left(\mathrm{g} \mathrm{m}^{-2}\right)$ in each season were calculated by integrating the hourly fluxes over time.

\section{Soil and Meteorological Parameters}

Soil samples of the 0-10 cm layer were collected at each air sampling event to quantify inorganic $\mathrm{N}$, gravimetric water content (by drying soil at $105^{\circ} \mathrm{C}$ ), and percent water filled pore space (WFPS). Soil bulk density in the $0-10 \mathrm{~cm}$ layer was measured using a cylinder $50 \mathrm{~mm}$ in diameter and $50 \mathrm{~mm}$ in height. WFPS was calculated from the gravimetric water content and bulk density using a particle density of $2.65 \mathrm{~g} \mathrm{~cm}^{-3}$.

For mineral $\mathrm{N}$ analysis, extraction with $2 \mathrm{M} \mathrm{KCl}$ was performed on field moist samples with correction for water content. Ammonium-N was determined using the Berthelot reaction with spectrometry at $647 \mathrm{~nm}$ (Kempers and Zweers 1986). Nitrate-N quantification was carried out by ultraviolet absorption spectrometry at $220 \mathrm{~nm}$ (Miyazawa and others 1985; Olsen 2008). Daily maximum, mean, and minimum temperatures and daily rainfall precipitation were obtained at a 
meteorological station located $1.5 \mathrm{~km}$ from the experimental site.

\section{Statistical Analysis}

$\mathrm{N}_{2} \mathrm{O}, \mathrm{CH}_{4}$, and $\mathrm{CO}_{2}$ fluxes were reported as means and standard error of the mean. Integrated data for each season were submitted to ANOVA after testing for normality and equal variance using $\mathrm{R}$ version 3.1.2 (2014), and, when significance was found, orthogonal polynomial contrast analysis was done at $5 \%$ probability.

Pearson correlation analysis was run to test for relationships between transformed GHG fluxes and pasture height, temperature, precipitation, \% WFPS, $\mathrm{NO}_{3}-\mathrm{N}$, and $\mathrm{NH}_{4}-\mathrm{N}$ using data from each sampling event within season.

\section{RESULTS}

\section{Environmental Conditions}

A total of $1468 \mathrm{~mm}$ rain fell at the study site in the first year of sampling, of which 438, 731, 229, and 69 fell during the spring, summer, autumn, and winter, respectively. In the second year, $966.5 \mathrm{~mm}$ rain fell, of which $452,359,88$, and $57 \mathrm{~mm}$ fell during the spring, summer, autumn, and winter, respectively. The amount of rain that fell during the rainy season was $65.8 \%$ of the 30 year period average from 1971 to 2010 (FCAV 2014). Historically, the region studied is characterized by warm rainy summers and mild dry winters; however, during the second year of this study, the summer and autumn were markedly dry (Fig. 1A).

All data analyzed in this study were obtained on the sampling days while the chambers were closed between 9:00 and 10:00 am. Mean air temperature was $25.3^{\circ} \mathrm{C}$. The lowest temperature recorded was $13.7^{\circ} \mathrm{C}$ in July 2013 , whereas the highest was $34.7^{\circ} \mathrm{C}$ in September 2014. During times in which the chambers were closed, temperatures inside ranged from -5.1 to $6.3^{\circ} \mathrm{C}$. Usually, the temperature increased during the $1-\mathrm{h}$ sampling period. However, the temperature tended to fall when the skies changed from sunny to cloudy during the sampling period.

WFPS of the surface soil $(0-10 \mathrm{~cm})$ varied seasonally in response to precipitation and grass growth (Fig. 1B). Soil WFPS tended to be greater in the summer. In both years, soil WFPS increased following summer rainfall; however, saturation of soil pores was reached only in January 2013. Isolated rainfall, which occurred in June and August 2013, also increased soil WFPS (Fig. 1B). A long period of low soil WFPS (around 30\%) occurred from April to September of 2014, probably because of low rainfall.

\section{$\mathrm{N}_{2} \mathrm{O}$ Flux}

Nitrous oxide emissions were greatest following rainfall events and application of urea fertilizer (Figs. 1A, 2A). $\mathrm{N}_{2} \mathrm{O}$ emissions were highest in the summers (Fig. 2A), whereas the other seasons had lower fluxes associated with frequent instances of $\mathrm{N}_{2} \mathrm{O}$ consumption. The maximum rate of $\mathrm{N}_{2} \mathrm{O}$ emissions was recorded in the second week of December 2013, when mean fluxes were 279, 394, and $469 \mu \mathrm{g} \mathrm{N} \mathrm{N}_{2} \mathrm{O}-\mathrm{N} \mathrm{m}^{-2} \mathrm{~h}^{-1}$ for light, moderate and heavy grazing intensity, respectively.

Negative fluxes were observed in approximately $60 \%$ of all $\mathrm{N}_{2} \mathrm{O}$ sampling events independently of grazing intensity and especially in the spring and autumn of the second year (Fig. 2A), when lower values of WFPS were also recorded (Fig. 1B). The highest rate of $\mathrm{N}_{2} \mathrm{O}$ consumption was measured on May 23, 2014 (autumn season), when mean fluxes were $-287,-235$, and $-299 \mu \mathrm{g} \mathrm{N}_{2} \mathrm{O}-\mathrm{N} \mathrm{m}^{-2} \mathrm{~h}^{-1}$ for light, moderate, and heavy grazing intensity, respectively.

Pasture height was significantly correlated with $\mathrm{N}_{2} \mathrm{O}$ flux during the summer. In the spring, $\mathrm{N}_{2} \mathrm{O}$ flux was strongly correlated with inorganic- $\mathrm{N}$ and temperature, and mildly correlated with \% WFPS. In the autumn, $\mathrm{N}_{2} \mathrm{O}$ flux was strongly correlated with \% WFPS and temperature, and mildly with $\mathrm{NH}_{4}{ }^{+}$(Table 2).

\section{$\mathrm{CH}_{4}$ Flux}

The highest levels of $\mathrm{CH}_{4}$ production and consumption (oxidation) occurred during the rainy season of 2013, followed by the rainy season of 2014. Indeed, $\mathrm{CH}_{4}$ flux fell by $50 \%$ in January 2014 (Fig. 2B), closely following the pattern of precipitation (Fig. 1A).

The highest variation in $\mathrm{CH}_{4}$ flux occurred in January 2013. The highest mean $\mathrm{CH}_{4}$ fluxes were 380,423 , and $504 \mu \mathrm{g} \mathrm{CH}_{4}-\mathrm{C} \mathrm{m}{ }^{-2} \mathrm{~h}^{-1}$ for light, moderate, and heavy grazing intensity, respectively. The highest mean $\mathrm{CH}_{4}$ oxidation values were $-544,-203$, and $-41 \mathrm{l} \mu \mathrm{g} \mathrm{CH}_{4}$-C for light, moderate, and heavy grazing intensity, respectively (Fig. 2B). The $\mathrm{CH}_{4}$ fluxes reported here had large daily standard errors, except during the rainy season. In the summer, $\mathrm{CH}_{4}$ flux was strongly correlated with $\mathrm{NH}_{4}{ }^{+}$content and mildly with temperature and precipitation. In the autumn and winter, $\mathrm{CH}_{4}$ fluxes were correlated only with temperature (Table 2). 

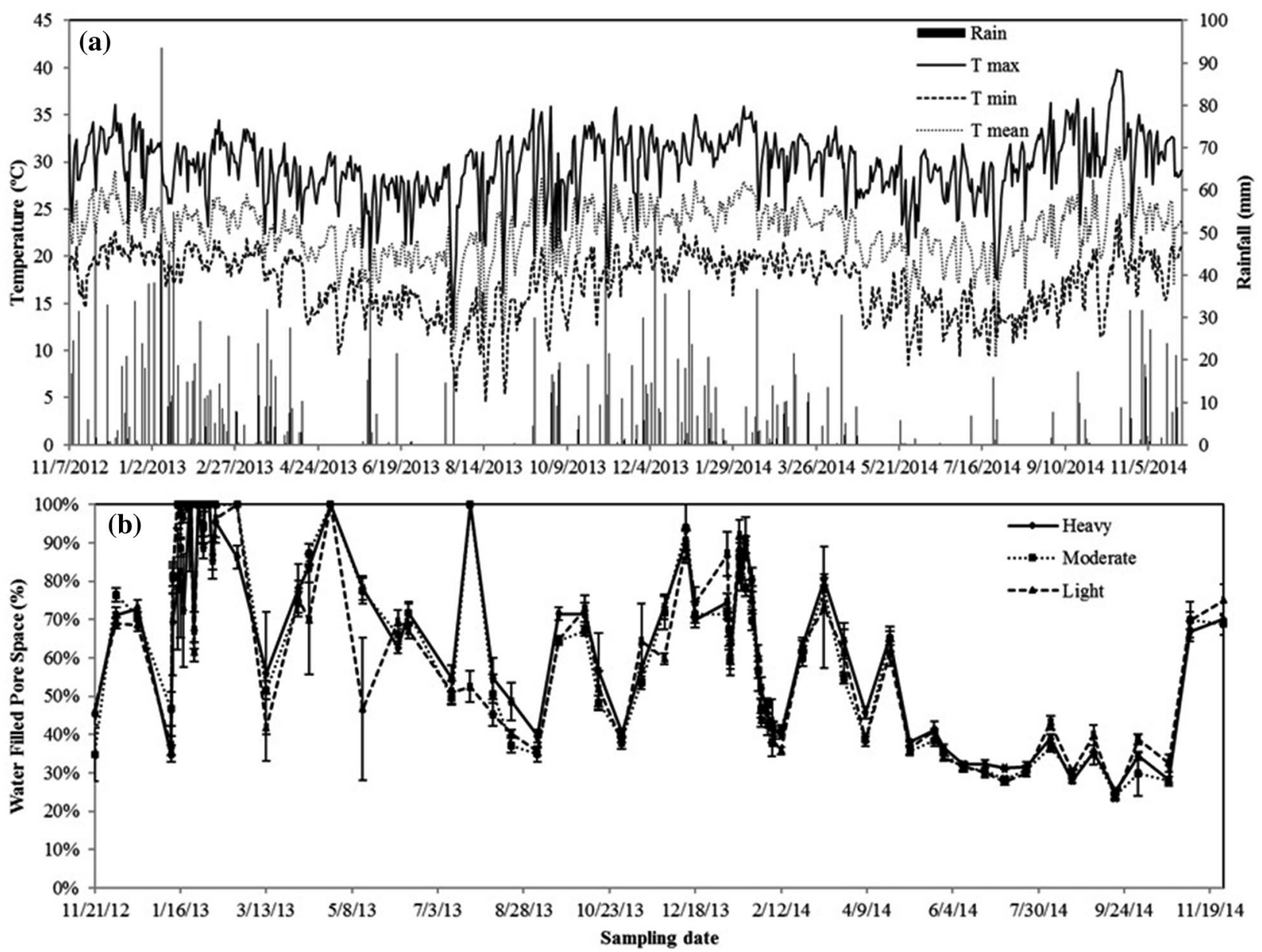

Figure 1. A Daily temperature (maximum, mean, and minimum; ${ }^{\circ} \mathrm{C}$ ) and precipitation (mm) and $\mathbf{B} \%$ WFPS for grazing intensity (light, moderate and heavy) during two years of evaluation (November 21, 2012 to November 26, 2014).

\section{$\mathrm{CO}_{2}$ Flux}

The highest levels of $\mathrm{CO}_{2}$ emissions occurred during the rainy summer season, when grass growth is favored, whereas the lowest levels were measured during the dry winter season. Intermediate levels of $\mathrm{CO}_{2}$ flux occurred in the spring and autumn (Figs. 1A, 2C). Indeed, the highest $\mathrm{CO}_{2}$ emission level $\left(\mathrm{l} \mathrm{g} \mathrm{m}^{-2} \mathrm{~h}^{-1}\right)$, which occurred in the light grazing intensity treatment, was measured on December 5, 2012, and again on February 26, 2014. The highest emission observed for the moderate grazing intensity occurred on February 1, $2013\left(885 \mathrm{mg} \mathrm{CO}_{2} \mathrm{~m}^{-2} \mathrm{~h}^{-1}\right)$, and for the heavy grazing intensity on December 5, 2012 (630 mg $\mathrm{CO}_{2} \mathrm{~m}^{-2} \mathrm{~h}^{-1}$ ). Minimal emissions were observed in the period of July to September of 2014 .

Percent WFPS was strongly correlated with $\mathrm{CO}_{2}$ emissions in the autumn and winter. $\mathrm{CO}_{2}$ emis- sions were also correlated with soil $\mathrm{NH}_{4}^{+}$in the autumn and with precipitation events in the winter (Table 2).

\section{Inorganic- $N$}

Inorganic- $\mathrm{N}$ was low throughout the study period. The sum of $\mathrm{NH}_{4}-\mathrm{N}$ and $\mathrm{NO}_{3}-\mathrm{N}$ totaled approximately $0.1-0.3 \%$ of total $\mathrm{N}$, which is the lowest level usually reported for inorganic- $\mathrm{N}$ in soils. The concentrations of soil $\mathrm{NH}_{4}-\mathrm{N}$ and $\mathrm{NO}_{3}-\mathrm{N}$ were similar and ranged from 5 to $25 \mathrm{mg} \mathrm{N} \mathrm{kg}^{-1}$ dry soil (Fig. 3A, B). As mentioned above, $\mathrm{NH}_{4}-\mathrm{N}$ was significantly correlated with $\mathrm{N}_{2} \mathrm{O}$ flux in the spring and autumn, with $\mathrm{CH}_{4}$ flux in the summer, and with $\mathrm{CO}_{2}$ emissions in the autumn. Soil $\mathrm{NO}_{3}-\mathrm{N}$ was correlated with $\mathrm{N}_{2} \mathrm{O}$ emissions in the spring (Table 2). 

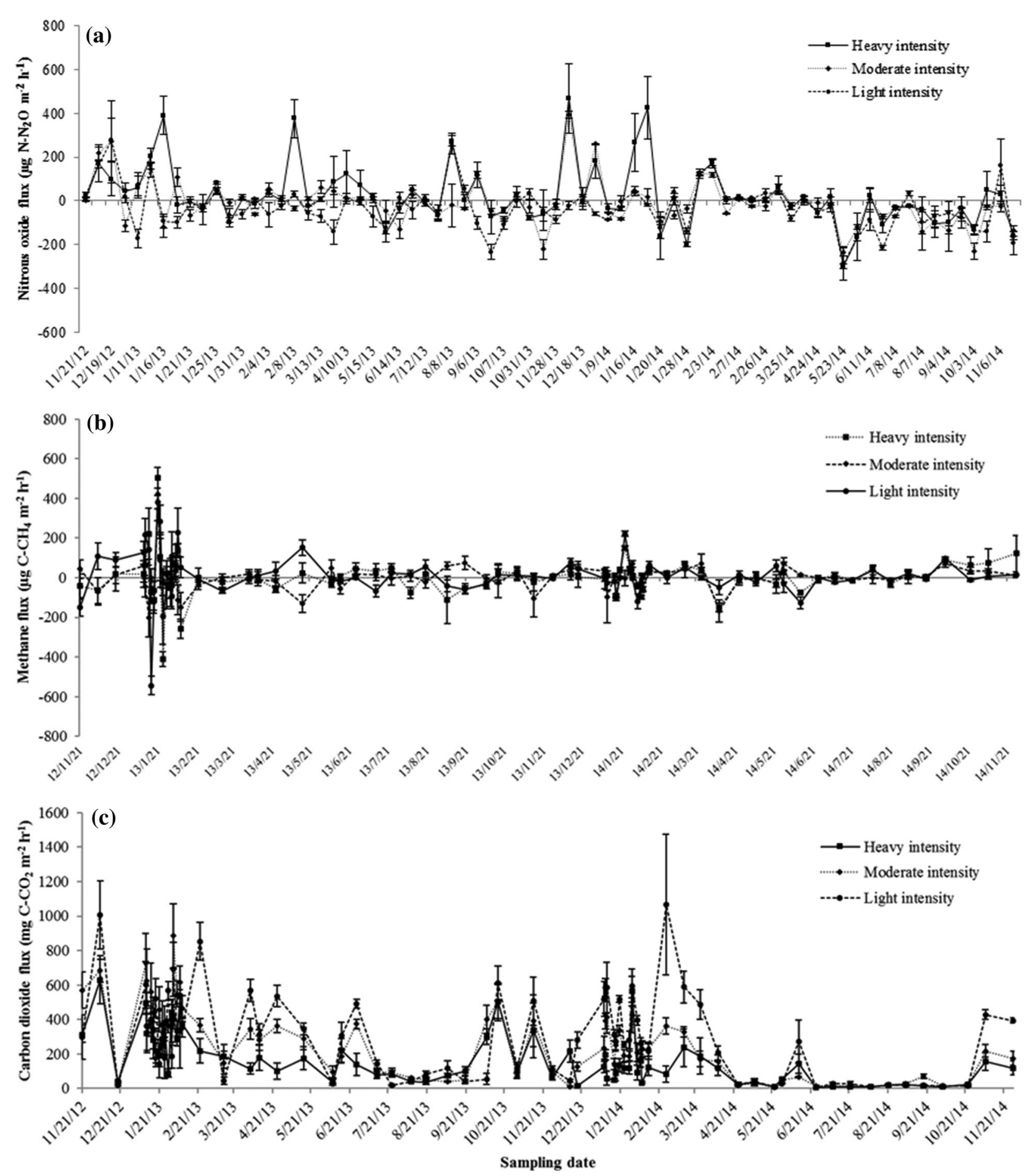

Figure 2. $\mathbf{A ~} \mathrm{N}_{2} \mathrm{O}$ flux ( $\mu \mathrm{g} \mathrm{N} \mathrm{N}_{2} \mathrm{O}-\mathrm{N} \mathrm{m}^{-2} \mathrm{~h}^{-1}$ ) and $\mathbf{B}$ fluxes of $\mathrm{CH}_{4}\left(\mu \mathrm{CH}_{4}-\mathrm{C} \mathrm{m}{ }^{-2} \mathrm{~h}^{-1}\right.$ ) and $\mathbf{C ~ C O}_{2}\left(\mathrm{mg} \mathrm{CO}_{2}-\mathrm{C} \mathrm{m}^{-2} \mathrm{~h}^{-1}\right)$ for the grazing intensities light, moderate, and heavy (respectively, 35, 25, and $15 \mathrm{~cm}$ pasture height) during two years of evaluation (November 21, 2012 to November 26, 2014).

\section{Cumulative Greenhouse Gas Emissions}

Table 3 shows a linear reduction in annual cumulative $\mathrm{N}_{2} \mathrm{O}$ emissions $(P<0.05)$ with increasing pasture height for both years, in other words, the highest emissions occurred in the heavy grazing intensity decreasing to the light. Light, moderate, 
Table 2. Pearson Correlation Coefficients $(r)$ for Assessing the Relation Between Fluxes of $\mathrm{N}_{2} \mathrm{O}$, $\mathrm{CH}_{4}$, and $\mathrm{CO}_{2}$ from Palisade-Grass Pastureland and Daily Explanatory Variables

\begin{tabular}{|c|c|c|c|c|c|c|c|c|}
\hline & Pasture height & $T_{\mathrm{i}}$ & $T_{\mathrm{f}}$ & Prec & $\%$ WFPS & $\mathrm{NH}_{4}^{+}$ & $\mathrm{NO}_{3}{ }^{-}$ & $\mathrm{CO}_{2}$ \\
\hline \multicolumn{9}{|l|}{$\mathrm{N}_{2} \mathrm{O}$} \\
\hline Spring & & $0.64^{* *}$ & $0.50 *$ & & 0.41 . & $0.66^{* *}$ & $0.50 *$ & \\
\hline Summer & -0.24 * & & & & & & & \\
\hline Autumn & & & $0.35 *$ & & 0.42 ** & $0.27^{\#}$ & & 0.27 \\
\hline \multicolumn{9}{|l|}{$\mathrm{CH}_{4}$} \\
\hline Summer & & -0.17 & & $0.22^{\#}$ & $0.21^{\#}$ & $0.35^{* *}$ & & \\
\hline Autumn & & & $0.39 * *$ & $0.28^{\#}$ & & & & \\
\hline Winter & & & -0.26 & & & & & \\
\hline \multicolumn{9}{|l|}{$\mathrm{CO}_{2}$} \\
\hline Autumn & & & & & $0.52 * *$ & $0.36^{*}$ & & \\
\hline Winter & & & & $0.38 *$ & $0.41^{* *}$ & & & \\
\hline
\end{tabular}

Explanatory variables: Pasture height; $T_{i}$, initial temperature; $T_{f}$, final temperature; Prec, precipitation, $\%$ WFPS, percent water-filled pore space; $N H_{4}{ }^{+}$, soil ammonium content; $\mathrm{NO}_{3}{ }^{-}$, soil nitrate content; $\mathrm{CO}_{2}, \mathrm{CO}_{2}$ flux.

Significance codes: ${ }^{\#} P<0.1,{ }^{*} P<0.05, * * P<0.01, * * * P<0.001$

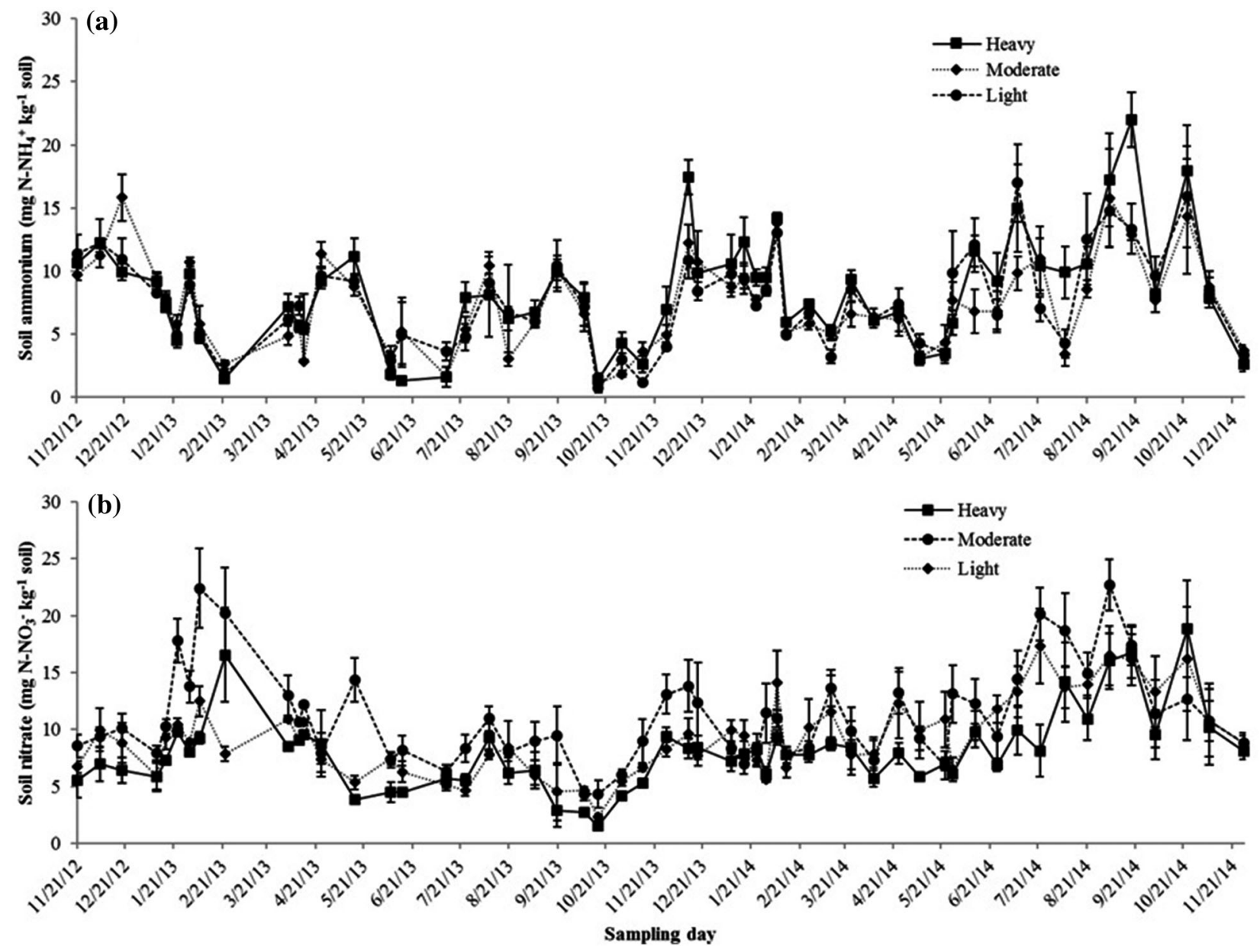

Figure 3. A Soil ammonium content ( $\mathrm{mg} \mathrm{NH}_{4}{ }^{+}-\mathrm{N} \mathrm{kg}^{-1}$ dry soil) and $\mathbf{B}$ soil nitrate content $\left(\mathrm{mg} \mathrm{NO}_{3}-\mathrm{N} \mathrm{kg}^{-1}\right.$ dry soil) for three grazing intensities light, moderate, and heavy (respectively, 35, 25, and $15 \mathrm{~cm}$ pasture height) during two years of evaluation (November 21, 2012 to November 26, 2014). 
Table 3. Cumulative $\mathrm{N}_{2} \mathrm{O}$ Emissions $\left(\mathrm{mg} \mathrm{N}_{2} \mathrm{O}-\mathrm{N} \mathrm{m}^{-2}\right.$ ) from Palisade-Grass Pastureland Managed at Light, Moderate, and Heavy Grazing Intensity (Respectively, 35, 25, and $15 \mathrm{~cm}$ Pasture Height) Across Seasons ${ }^{1}$ and Years

\begin{tabular}{|c|c|c|c|c|c|}
\hline & Spring & Summer & Autumn & Winter & Total year \\
\hline \multicolumn{6}{|l|}{ Year 1} \\
\hline Light & $76.5(42.5)$ & $-11.7(39.5)$ & $-102.3(19.5)$ & $-10.8(45.6)$ & $-48.3(118.9)$ \\
\hline Moderate & $80.5(44.2)$ & $-28.8(51.0)$ & $-1.3(34.7)$ & $-8.8(34.2)$ & $41.6(127.4)$ \\
\hline Heavy & $46.3(14.1)$ & $128.4(20.5)$ & $33.2(39.2)$ & $92.3(25.0)$ & $300.1(49.3)$ \\
\hline Mean & $67.8(20.0)$ & $29.3(27.2)$ & $-23.5(22.4)$ & $24.2(22.7)$ & $97.81(67.1)$ \\
\hline Effect $^{2}$ & ns & $L^{*}$ & $\mathrm{~L}^{* * *}$ & ns & $\mathrm{L}^{*}$ \\
\hline$R^{2}$ & & 0.51 & 0.60 & & 0.52 \\
\hline \multicolumn{6}{|l|}{ Year 2} \\
\hline Light & $-101.4(56.5)$ & $10.54(14.5)$ & $-221.8(37.2)$ & $-166.6(32.4)$ & $-479.2(91.1)$ \\
\hline Moderate & $-48.1(26.3)$ & $61.02(15.6)$ & $-127.1(10.8)$ & $-149.5(76.2)$ & $-263.7(90.8)$ \\
\hline Heavy & $9.2(51.1)$ & $91.64(32.8)$ & $-107.1(12.4)$ & $-147.0(55.3)$ & $-153.2(88.7)$ \\
\hline Mean & $-46.7(27.5)$ & $54.40(14.7)$ & $-152.0(17.6)$ & $-154.3(31.7)$ & $-298.7(58.9)$ \\
\hline Effect $^{2}$ & ns & $\mathrm{L}^{*}$ & $\mathrm{~L}^{* * *}$ & ns & $\mathrm{L}^{*}$ \\
\hline$R^{2}$ & & 0.55 & 0.66 & & 0.55 \\
\hline
\end{tabular}

${ }^{1}$ Rainy summer, dry winter, transitional spring, and autumn. Within parentheses: \pm standard error of the mean (SEM). Anova significance: year, $P<0.01 ;$ season $P<0.01$; pasture height, $P<0.01$; spring, $n=7$; summer, $n=15$; autumn, $n=7$; winter, $n=7$.

${ }^{2}$ Effect for different grazing intensities $\left(15,25\right.$, and 35 pasture heights) on accumulated $N_{2} O . L=$ linear. Significance codes: $P<0.1, * P<0.05, * * P<0.01, * * * P<0.001$.

Table 4. Cumulative $\mathrm{CH}_{4}$ Emissions $\left(\mathrm{mg} \mathrm{CH}_{4}-\mathrm{C} \mathrm{m}^{-2}\right)$ from Palisade-Grass Pastureland Managed at Light, Moderate, and Heavy Grazing Intensity (respectively, 35, 25, and $15 \mathrm{~cm}$ pasture height) Across Seasons ${ }^{1}$ and Years

\begin{tabular}{|c|c|c|c|c|c|}
\hline & Spring & Summer & Autumn & Winter & Total year \\
\hline \multicolumn{6}{|l|}{ Year 1} \\
\hline Light & $34.2(32.1)$ & $2.7(1.5)$ & $80.4(36.8)$ & $-4.7(24.6)$ & 112.5 \\
\hline Moderate & $-9.6(21.3)$ & $-0.8(1.0)$ & $-72.1(35.3)$ & $42.0(25.4)$ & $-40.5(60.0$ \\
\hline Heavy & $-21.5(30.8)$ & $-0.5(1.4)$ & $-21.3(24.6)$ & $14.7(20.6)$ & $-28.6(60.9$ \\
\hline Mean & $1.0(16.5)$ & $0.5(0.8)$ & $-4.3(23.5)$ & $17.3(13.6)$ & $14.5(37.9)$ \\
\hline Effect $^{2}$ & ns & ns & L. & ns & ns \\
\hline$R^{2}$ & & & 0.43 & & \\
\hline \multicolumn{6}{|l|}{ Year 2} \\
\hline Light & $54.2(16.4)$ & $45.0(16.4)$ & $-45.2(25.8)$ & $2.8(12.5)$ & $56.8(35.7)$ \\
\hline Moderate & $81.4(15.2)$ & $5.1(14.9)$ & $-25.2(36.0)$ & $1.3(20.0)$ & $62.2(41.5)$ \\
\hline Heavy & $119.1(72.4)$ & $19.6(8.1)$ & $-68.5(12.2)$ & $7.4(12.3)$ & $70.6(70.3)$ \\
\hline Mean & $84.8(24.3)$ & $23.4(8.4)$ & $-43.3(8.4)$ & $3.9(8.4)$ & $65.6(28.0)$ \\
\hline Effect $^{2}$ & $L^{*}$ & ns & ns & ns & ns \\
\hline$R^{2}$ & 0.46 & & & & \\
\hline
\end{tabular}

${ }^{1}$ Rainy summer, dry winter, transitional spring, and autumn. Within parentheses: \pm standard error of the mean (SEM). Anova significance: year, $P=0.23 ;$ season, $P<0.01$; pasture height, $P<0.01$; spring, $n=7$; summer, $n=15$; autumn, $n=7$; winter, $n=7$.

${ }^{2}$ Effect for different grazing intensities $\left(15,25\right.$, and 35 pasture heights) on accumulated $\mathrm{CH}_{4}$ emitted. $L=$ linear. Significance codes: $P<0.1, * P<0.05, * * P<0.01$, $* * * P<0.001$.

and heavy grazing had total $\mathrm{N}_{2} \mathrm{O}$ emissions of -48.3 , 41.6 , and $300.1 \mathrm{mg} \mathrm{N}_{2} \mathrm{O}-\mathrm{N} \mathrm{m}^{-2}$ in year 1 and totals of $-298.7,-263.7$, and $-153.2 \mathrm{mg} \mathrm{N}_{2} \mathrm{O}-\mathrm{N} \mathrm{m}^{-2}$ in year 2 , respectively. The heavy grazing intensity had the highest levels of $\mathrm{N}_{2} \mathrm{O}$ emissions in all seasons except for in the spring of year 1. The light and moderate grazing intensity had cumulative $\mathrm{N}_{2} \mathrm{O}$ emissions only in the spring of year 1 and in the summer of year 2. The effect of pasture height on cumulative $\mathrm{N}_{2} \mathrm{O}$ emissions was negatively linear in the annual analysis $(P<0.05)$, driven by the negative associations observed in the summer $(P<0.05)$ and even more so in autumn $(P<0.001)$.

Annual cumulative $\mathrm{CH}_{4}$ emissions were not affected by grazing intensity treatment (Table 4). In 
Table 5. Cumulative $\mathrm{CO}_{2}$ Emissions $\left(\mathrm{Mg} \mathrm{CO}_{2} \mathrm{ha}^{-1}\right)$ from Palisade-Grass Pastureland Managed at Light, Moderate, and Heavy Grazing Intensity (respectively, 35, 25, and $15 \mathrm{~cm}$ pasture height) Across Seasons ${ }^{1}$ and Years

\begin{tabular}{|c|c|c|c|c|c|}
\hline & Spring & Summer & Autumn & Winter & $\overline{\text { Total year }}$ \\
\hline \multicolumn{6}{|l|}{ Year 1} \\
\hline Light & $26.8(2.9)$ & $31.8(1.8)$ & $28.3(1.8)$ & $10.9(1.0)$ & $97.8(4.7)$ \\
\hline Moderate & $23.0(2.7)$ & $29.1(2.94)$ & $22.7(1.7)$ & $9.0(0.7)$ & $83.7(4.0)$ \\
\hline Heavy & $25.0(3.8)$ & $20.6(1.6)$ & $11.8(2.7)$ & $6.9(0.7)$ & $64.3(2.9)$ \\
\hline Mean & $24.9(1.8)$ & $27.2(1.7)$ & $20.9(2.0)$ & $8.9(0.6)$ & $81.9(3.9)$ \\
\hline Effect $^{2}$ & ns & $\mathrm{L}^{* * *}$ & $L^{* * *}$ & $L^{* * *}$ & $\mathrm{~L}^{* * *}$ \\
\hline$R^{2}$ & & 0.67 & 0.82 & 0.67 & 0.84 \\
\hline \multicolumn{6}{|l|}{ Proportion } \\
\hline Light & $27.4 \%$ & $32.5 \%$ & $29.0 \%$ & $11.1 \%$ & \\
\hline Moderate & $27.4 \%$ & $34.8 \%$ & $27.1 \%$ & $10 . \%$ & \\
\hline Heavy & $38.8 \%$ & $32.1 \%$ & $18.4 \%$ & $10.7 \%$ & \\
\hline \multicolumn{6}{|l|}{ Year 2} \\
\hline Light & $12.1(2.3)$ & $37.8(7.0)$ & $10.5(1.4)$ & $1.9(0.5)$ & $62.3(7.4)$ \\
\hline Moderate & $7.2(0.5)$ & $20.7(1.9)$ & $5.8(0.6)$ & $1.9(0.3)$ & $35.1(1.9)$ \\
\hline Heavy & $6.8(0.8)$ & $10.0(2.0)$ & $6.0(1.6)$ & $1.3(0.1)$ & $24.1(3.3)$ \\
\hline Mean & $8.7(1.0)$ & 22.7 (3.7) & $7.4(0.9)$ & $1.7(0.2)$ & $40.5(4.7)$ \\
\hline Effect $^{c}$ & $L^{*}$ & $L^{* * *}$ & $\mathrm{~L}^{*}$ & ns & $\mathrm{L}^{* * *}$ \\
\hline$R^{2}$ & 0.55 & 0.75 & 0.51 & & 0.81 \\
\hline \multicolumn{6}{|l|}{ Proportion } \\
\hline Light & $19.5 \%$ & $60.7 \%$ & $16.8 \%$ & $3.0 \%$ & \\
\hline Moderate & $20.6 \%$ & $57.4 \%$ & $16.6 \%$ & $5.4 \%$ & \\
\hline Heavy & $28.1 \%$ & $41.6 \%$ & $25.0 \%$ & $5.4 \%$ & \\
\hline
\end{tabular}

${ }^{1}$ Rainy summer, dry winter, transitional spring, and autumn. Within parentheses: \pm standard error of the mean (SEM). Anova significance: year, $P$ < 0.01; season, $P<0.01$; pasture height, $P<0.01$; spring, $n=7$; summer, $n=15$; autumn, $n=7$; winter, $n=7$.

${ }^{2}$ Effect for different grazing intensities $\left(15,25\right.$, and 35 pasture heights) on accumulated $\mathrm{CO}_{2}$ emitted: $L=$ linear. Significance codes: ${ }^{* P}<0.05, * * P<0.01, * * * P<0.001$.

year 1 , net oxidation occurred in the moderate and heavy grazing intensity, totaling -40.5 and $-28.6 \mathrm{mg}$ $\mathrm{CH}_{4}-\mathrm{C} \mathrm{m}^{-2}$, respectively. In year 2 , net production for the for light, moderate, and heavy grazing intensity was 56.8, 62.2, and $70.6 \mu \mathrm{g} \mathrm{CH}_{4}-\mathrm{C} \mathrm{m}^{-2}$, respectively. Cumulative $\mathrm{CH}_{4}$ emissions were negatively associated with pasture height only in the autumn of year 1 and in the spring of year $2(P<0.05)$.

Table 5 shows that annual cumulative $\mathrm{CO}_{2}$ emissions were positively associated with pasture height in both years of study $(P<0.001)$. Indeed, for light, moderate, and heavy grazing intensity, cumulative $\mathrm{CO}_{2}$ emissions totaled 81.9, 83.7, and $64.3 \mathrm{Mg} \mathrm{CO}_{2} \mathrm{ha}^{-1}$ in year $\mathrm{l}$ and 62.3, 35.1, and $24.1 \mathrm{Mg} \mathrm{CO} \mathrm{Ca}^{-1}$ in year 2, respectively. The reduction of $35 \%$ in the amount of precipitation that occurred in year 2 was probably responsible for the sharp drop in the cumulative $\mathrm{CO}_{2}$ emissions in that year.

Pasture height was positively associated with cumulative $\mathrm{CO}_{2}$ emissions in all seasons, except for spring of year 1 and winter of year 2. The summers of
2013 and 2014 accounted for approximately $35 \%$ and $50 \%$ of annual cumulative $\mathrm{CO}_{2}$ emissions, respectively. In contrast, the winters of 2013 and 2014 accounted for just $10 \%$ and $5 \%$ of annual cumulative $\mathrm{CO}_{2}$ emissions, respectively. Spring and autumn accounted for approximately $27 \%$ and $20 \%$ of annual cumulative $\mathrm{CO}_{2}$ emissions, respectively, in both years (Table 5). The contribution of each season to annual cumulative $\mathrm{CO}_{2}$ emissions was probably affected by the amount of precipitation in each season.

\section{Discussion}

\section{$\mathrm{N}_{2} \mathrm{O}$ Flux}

Once fertilizer was applied, soil water content and its consequent effect on WFPS were the key driving variables for $\mathrm{N}_{2} \mathrm{O}$ emission from grassland in the summer months. Soil water content depends on the amount of rainfall and how rapidly rain infiltrates into the soil (Dobbie and others 1999). In our study, the highest $\mathrm{N}_{2} \mathrm{O}$ fluxes occurred in the 
summer and following rainfall events. Rainfall events increased WFPS levels to above $60-70 \%$, which create good conditions for anaerobic denitrification (Smith and others 2003). Rainfall can stimulate $\mathrm{N}_{2} \mathrm{O}$ emissions, as has been observed in other studies (van der Weerden and others 2011; Sordi and others 2013). Previous study showed that grazing significantly increased $\mathrm{N}_{2} \mathrm{O}$ flux during the growing season (Hu and others 2010; Zhu and others 2015) and may have contributed to the higher fluxes found in the present study in the summer, which correspond with the growing season in the Cerrado region. Most studies of temperate regions have reported that $\mathrm{N}_{2} \mathrm{O}$ emissions increase in the cooler/wetter compared with warmer/drier periods of the year (Allen and others 1996; Zaman and Nguyen 2012; Rochette and others 2014). In contrast, the seasonal variability of $\mathrm{N}_{2} \mathrm{O}$ emissions has a different pattern in tropical grasslands, where the warm and wet summer has the highest fluxes. Lessa and others (2014) found large differences in $\mathrm{N}_{2} \mathrm{O}$ emissions between seasons, with the lowest $\mathrm{N}_{2} \mathrm{O}$ emissions in the dry winter season, a result similar to ours. Here, we show that the dry winter season had lower values of \% WFPS (30-40\%) and lower temperatures, both of which may help explain the low level of $\mathrm{N}_{2} \mathrm{O}$ release. Variations in soil moisture drove the seasonal variations in $\mathrm{N}_{2} \mathrm{O}$ fluxes in line with Zhang and others (2015), who observed a similar effect in temperate grasslands in Inner Mongolia, Northern China.

Mechanisms of $\mathrm{N}_{2} \mathrm{O}$ consumption in tropical grasslands need to be studied. A plausible explanation for the negative $\mathrm{N}_{2} \mathrm{O}$ fluxes found in all seasons depends on the occurrence of an equilibrium between the concentration of $\mathrm{N}_{2} \mathrm{O}$ in soil pores and that in the atmosphere at the surface of the grassland (Gas diffusion). According to Mazzetto and others (2014), one possible mechanism for $\mathrm{N}_{2} \mathrm{O}$ uptake is a lack of available nitrate in the soil, leading denitrifying bacteria to use $\mathrm{N}_{2} \mathrm{O}$ as an electron acceptor, which in turn contributes to net $\mathrm{N}_{2} \mathrm{O}$ uptake. Low values of mineral $\mathrm{N}$ and high values of \% WFPS have been shown to favor $\mathrm{N}_{2} \mathrm{O}$ consumption (Chapuis-Lardy and others 2007; Mazzetto and others 2014). The flux of $-299 \mu \mathrm{g}$ $\mathrm{N}_{2} \mathrm{O}-\mathrm{N} \mathrm{m}^{-2} \mathrm{~h}^{-1}$ reported here may be the lowest value of $\mathrm{N}_{2} \mathrm{O}$ flux ever reported, exceeding the uptake rate of $-207 \mu \mathrm{g} \mathrm{N} \mathrm{N}_{2} \mathrm{O}-\mathrm{N} \mathrm{m}^{-2} \mathrm{~h}^{-1}$ reported by Blicher-Mathiesen and Hoffmann (1999). Schlesinger (2013) suggested that uptake rates greater than $20 \mu \mathrm{g} \mathrm{N}_{2} \mathrm{O}-\mathrm{N} \mathrm{m}^{-2} \mathrm{~h}^{-1}$ are related to wet soil, which is inconsistent with our findings.

\section{$\mathrm{CH}_{4}$ Flux}

Seasonal variation in $\mathrm{CH}_{4}$ emissions has been associated with temperature and insolation (Sorrell and Boon 1992) as well as with air temperature and moisture (Mazzetto and others 2014). We observed the highest levels of both production and oxidation of $\mathrm{CH}_{4}$ in the rainy summer season. The high rate of evapotranspiration that occurred at our site may explain the rapid variation between $\mathrm{CH}_{4}$ production and oxidation. Indeed, various environmental conditions allow methanotroph expression in soils subjected to moisture variation, during which their methanotrophic potential is maintained because they remain viable in anaerobiosis (Roslev and King 1994; Le Mer and Roger 2001).

During the autumn and winter, temperature was correlated with $\mathrm{CH}_{4}$ flux, and thus temperature appears to control $\mathrm{CH}_{4}$ production and oxidation during these seasons. However, an explanation for this observation is hindered by the lack of consistent results among several other publications. Indeed, Chiavegato and others (2015) found no association between $\mathrm{CH}_{4}$ flux and either soil water content or soil or air temperature. Likewise, Dengel and others (2011), measuring $\mathrm{CH}_{4}$ in a grassland site, found no relationship with air temperature. On the other hand, and in accordance with our results, Chamberlain and others (2015) found an association between $\mathrm{CH}_{4}$ emissions and soil temperature. We found that emissions during the warm season (end of spring and summer) were much higher than in winter (mild and dry). Other studies of $\mathrm{CH}_{4}$ emissions have also reported that emissions were higher in the summer and lower in the winter (Holter 1997; Mazzetto and others 2014). Contrarily, Zhu and others (2015) showed in an alpine meadow on the Tibetan Plateau that warming significantly increased the $\mathrm{CH}_{4}$ oxidation rate in line with Carter and others (2012), who studied $\mathrm{CH}_{4}$ uptake in European peatlands and shrublands.

Differences of $\mathrm{CH}_{4}$ emissions/oxidation could be due to differences in grazing intensity and climate conditions (Zhu and others 2015). We observed a significant effect of grazing intensity on $\mathrm{CH}_{4}$ emissions. Grazing can affect $\mathrm{CH}_{4}$ flux due to soil compaction caused by animal trampling which may decrease $\mathrm{O}_{2}$ diffusion into the soil and does not favor $\mathrm{CH}_{4}$ oxidation because of the reduction in $\mathrm{O}_{2}$ availability (Saggar and others 2007; Liu and others 2007). Our findings differ from those of others (Chen and others 2011; Zhu and others 2015), who found that grazing did not significantly affect $\mathrm{CH}_{4}$ fluxes. 


\section{$\mathrm{CO}_{2}$ Flux}

$\mathrm{CO}_{2}$ flux has been reported to be influenced by season, soil, and climatic variables $(\mathrm{Xu}$ and Baldocchi 2004; Wohlfahrt and others 2008; Thomas and others 2014). In our study, the highest $\mathrm{CO}_{2}$ fluxes occurred at the end of spring and in the summer. During these periods, we observed increased grass growth and higher rainfall, which may have favored root and soil microorganism respiration. We observed low fluxes in the winter, when temperature and precipitation are lower. However, no explanatory variable was associated with $\mathrm{CO}_{2}$ flux in the summer and spring, whereas it was significantly correlated with precipitation and $\%$ WFPS in the autumn and winter (Table 1). We suggest that soil water controlled $\mathrm{CO}_{2}$ flux in the latter two seasons in line with Gong and others (2014), who measured $\mathrm{CO}_{2}$ emissions in cold and arid environments and found that soil water content played a critical role in soil respiration. Brito and others (2015) found a positive linear association between $\mathrm{CO}_{2}$ flux and soil temperature in summer and autumn. They proposed that seasonal variation of $\mathrm{CO}_{2}$ was directly related to variations in precipitation and soil temperature. Immediately following re-wetting, soil $\mathrm{CO}_{2}$ efflux rates can be very high (Thomas and Hoon 2010). We also found high $\mathrm{CO}_{2}$ fluxes in the spring, after the rainy season began (Fig. 2) and \% WFPS increased (Fig. 1B).

\section{Cumulative Greenhouse Gas Emissions}

The differences in $\mathrm{N}_{2} \mathrm{O}$ emissions between seasons are difficult to interpret. Van Groenigen and others (2005) proposed that such variations are more likely to occur due to fertilization schedules than to urine deposition. In the present study, we found higher amounts of cumulative $\mathrm{N}_{2} \mathrm{O}$ emissions in the spring and summer, when fertilizer was applied to the soil.

Grassland management affected $\mathrm{N}_{2} \mathrm{O}$ emission accumulation in the summer, autumn, and annually, whereas in the spring and winter it did not (Table 2). The amount of $\mathrm{N}_{2} \mathrm{O}$ emitted/consumed decreased from the heavy grazing intensity to the light in line with Klumpp and others (2011). Pastures with heavy grazing intensity have a lower demand for nitrogen for growth. Moreover, the higher stocking rate in the heavy grazing intensity treatment resulted in more nitrogen being returned to the soil, although deposition of feces and urine favor N losses (Haynes and Williams 1993). Under light grazing intensity, more litter is produced with a high $\mathrm{C} / \mathrm{N}$ ratio, which in turn, requires more $\mathrm{N}$ for decomposition and $\mathrm{N}$ mineralization (Shariff and others 1994), thereby resulting in less $\mathrm{N}$ available to be lost as well as this is a low $\mathrm{N}$ system; thus $\mathrm{N}$ uptake by grass is perhaps more likely than $\mathrm{N}_{2} \mathrm{O}$ emissions. However, in other cases, for instance, Zou and others (2005) established a positive linear relationship between aboveground plant biomass and $\mathrm{N}_{2} \mathrm{O}$ emissions in line with Zhang and others (2015). They suggest that reducing plant litter and aboveground biomass might result in decreases in the substrates supplied to microbes, which are involved in nitrification and denitrification process. These differences in $\mathrm{N}_{2} \mathrm{O}$ emissions cannot be interpreted without considering nitrogen recycling from animal excreta. In some cases, as observed in the higher grazing intensity, the main source of $\mathrm{N}$ is animal excreta which might augment $\mathrm{N}_{2} \mathrm{O}$ production compared to that with higher pasture height (higher aboveground biomass) but with lower animal stocks and lower $\mathrm{N}$ returning from animal excreta. Some soil properties have an important roles in $\mathrm{N}_{2} \mathrm{O}$ production. When soil properties like texture, chemical composition and bulk density were similar in the different paddocks (Table 1) we were not able to attribute effects of this variable on cumulative $\mathrm{N}_{2} \mathrm{O}$ emissions.

Cumulative $\mathrm{N}_{2} \mathrm{O}$ emissions were lower in winter than in summer in a subtropical pastureland of the southern Brazilian state Paraná (Sordi and others 2013), almost zero in the Cerrado (Lessa and others 2014), and negative in a grassland of the Brazilian state Rondônia in the Amazon region (Mazzetto and others 2014), consistent with the current study. Decreases in $\mathrm{N}_{2} \mathrm{O}$ production in drier weather similar to our winter probably occur due to reduced denitrification (Carter and others 2012). Our data agree with studies conducted in tropical regions and differ from those conducted in temperate regions. In temperate regions, winters are usually wet, thereby favoring anaerobiosis and low $\mathrm{N}$ uptake by plants, which in turn augment $\mathrm{N}$ availability for $\mathrm{N}_{2} \mathrm{O}$ emission (Allen and others 1996; Luo and others 2008). In these regions, higher soil water content in cooler periods of the year favors $\mathrm{N}_{2} \mathrm{O}$ production by denitrification (Zaman and Nguyen 2012), and, in areas where pasture is irrigated, small differences in emissions between seasons are observed (Kelly and others 2008).

In our study, we did not observe a clear pattern of $\mathrm{CH}_{4}$ flux variation within each season. However, we found significant effects on $\mathrm{CH}_{4}$ production and oxidation between seasons. Similar effects were reported by Chamberlain and others (2015), whereas the opposite was shown by Chiavegato 
and others (2015). Net $\mathrm{CH}_{4}$ production occurred in all seasons except autumn. At the study site, rainfall diminished during autumn, which reduced soil moisture content and thus may have favored $\mathrm{CH}_{4}$ oxidation. Conversely, higher rainfall during spring coupled with the rotting of the accumulated grass litter probably contributed to the increase in $\mathrm{CH}_{4}$ emissions observed in the spring of 2014 (Table 4).

Dung is the main source of $\mathrm{CH}_{4}$ released to the atmosphere from grassland soils (Saggar and others 2004). In the present study, $\mathrm{CH}_{4}$ production and oxidation were affected by pasture grazing intensity; however, we did not observe a clear trend, because in year 1 , the heavy grazing intensity had lower $\mathrm{CH}_{4}$ production whereas in year 2 it had the highest cumulative emissions. Soil parameters and climate variables affect $\mathrm{CH}_{4}$ dynamics, as reviewed by Le Mer and Roger (2001) and Saggar and others (2004). Indeed, although soil and climate variables affected $\mathrm{CH}_{4}$ production in our study, we cannot exclude the role of other variables not investigated here.

We observed that $\mathrm{CH}_{4}$ emissions were higher in the heavy grazing intensity, decreased in the light in the spring and in autumn was lower in the heavy grazing intensity increasing to the light. Heavy grazing intensity implies high deposition of excreta, which favors $\mathrm{CH}_{4}$ production in the spring. The pattern of urination and defecation in paddocks varies widely (Haynes and Williams 1993; Gusmao and others 2015). Cumulative $\mathrm{CH}_{4}$ production and oxidation had higher standard errors than did other GHG (Table 4), suggesting that spatial variation in $\mathrm{CH}_{4}$ flux may be associated with the spatial variability of excreta deposition.

Seasonal variability of $\mathrm{CO}_{2}$ emissions has been attributed to precipitation and soil temperature in a tropical pasture (Brito and others 2015). Thus, in the present study, the observed variability in precipitation may explain the interannual differences in $\mathrm{CO}_{2}$ emissions. From year 1 to year 2, precipitation declined by $35 \%$ whereas cumulative $\mathrm{CO}_{2}$ emissions decreased by $50 \%$. The warm and rainy summer season contributed $35 \%$ and $50 \%$ of total $\mathrm{CO}_{2}$ emissions in year 1 and year 2 , respectively. In the region studied, there is seasonality in grass growth and biomass production, which occurs mainly in the summer (de Pinho Costa and others 2006), consequently $\mathrm{CO}_{2}$ emissions probably varied with grass growth.

Grazing intensity had a positive linear effect on cumulative $\mathrm{CO}_{2}$ flux, both annually and by season. A higher stocking rate was necessary to maintain a heavy grazing intensity (Barbero and others 2015). Wang and others (2009) observed that $\mathrm{CO}_{2}$ fluxes were decreased significantly at a high stocking rate, which might have been related to the low soil moisture and biomass at the study site. A high pasture height under light grazing intensity implies high aboveground biomass and litter deposition (Shariff and others 1994), resulting in a greater amount of $\mathrm{C}$ that can be released through decomposition. Laporte and others (2002) found a positive effect of aboveground plant biomass on soil surface $\mathrm{CO}_{2}$ efflux at a grassland site in line with Cao and others (2004) who showed that increasing aboveground and belowground biomass augmented plant autotrophic respiration. Bremer and others (1998) reported reduced $\mathrm{CO}_{2}$ fluxes in grazed versus ungrazed tallgrass prairie. They suggested that the reduction in photosynthetic surface area and available carbohydrates was the dominant factor driving lowered respiration rates. In contrast, Gong and others (2014) found no significant change in $\mathrm{CO}_{2}$ fluxes despite detecting a tendency of plant cover and above- or belowground biomass, and that was in line with the observations by Liebig and others (2013) in the semiarid northern Great Plains of North America.

Optimal pasture management aims to mitigate GHG emissions. Here we presented some of the first research in which GHG production was measured for different grazing intensities. We observed that grazing intensity affected GHG emissions. Higher $\mathrm{N}_{2} \mathrm{O}$ emissions were found in the heavy grazing intensity. Managing pastures for light grazing intensity and avoiding overgrazing can reduce $\mathrm{N}_{2} \mathrm{O}$ emissions as well as improve $\mathrm{C}$ sequestration in the soil, which may compensate in part for GHG emissions during animal production.

\section{Conclusions}

Fluxes of $\mathrm{N}_{2} \mathrm{O}, \mathrm{CH}_{4}$, and $\mathrm{CO}_{2}$ varied among seasons and between years. The magnitude of fluxes observed in this study can be explained by seasonal variations in temperature, precipitation, \% WFPS, and inorganic $\mathrm{N}$ content.

Temperature was associated with $\mathrm{N}_{2} \mathrm{O}$ fluxes in the spring and autumn and with $\mathrm{CH}_{4}$ fluxes in summer, autumn and winter. \%WFPS and ammonium content were correlated with $\mathrm{N}_{2} \mathrm{O}$ fluxes in the spring and autumn, with $\mathrm{CH}_{4}$ fluxes in the summer and $\mathrm{CO}_{2}$ in autumn. Nitrate was correlated with $\mathrm{N}_{2} \mathrm{O}$ emissions in spring and \%WFPS with $\mathrm{CO}_{2}$ efflux in the winter. Cumulative $\mathrm{N}_{2} \mathrm{O}$ and $\mathrm{CO}_{2}$ emissions were influenced by year and season, whereas $\mathrm{CH}_{4}$ was affected by season.

Grazing intensity had a negative linear effect on annual, summer, and autumn cumulative $\mathrm{N}_{2} \mathrm{O}$ 
emissions/consumption and a positive linear effect on annual cumulative $\mathrm{CO}_{2}$ emissions.

\section{ACKNOWLEDGMENTS}

This work is funded by the "São Paulo Research Foundation" (Fapesp grants \# 2011/00060-8, \# 2012/06718-8, \# 2012/14956-6, \# 2012/04605-1). The authors ASC, ESM, and RPB thank FAPESP for their scholarships. The authors ACR, LFB, ERJ, and RAA be grateful the Conselho Nacional de Desenvolvimento Científico Tecnológico $(\mathrm{CNPq})$ and Coordenação de Aperfeiçoamento de Pessoal de Nível Superior (CAPES) for the scholarships. The authors would like to thank the anonymous reviewers for their valuable comments and suggestions to improve the quality of this paper and to Publicase, for the assistance with proofreading the article.

\section{CONFLICT OF INTEREST}

The authors declare that they have no conflict of interest.

\section{REFERENCES}

Allen AG, Jarvis SC, Headon DM. 1996. Nitrous oxide emissions from soils due to inputs of nitrogen from excreta return by livestock on grazed grassland in the UK. Soil Biol Biochem 28:597-607.

Alves BJR, Smith KA, Flores RA, Cardoso AS, Oliveira WRD, Jantalia CP, Urquiaga S, Boddey RM. 2012. Selection of the most suitable sampling time for static chambers for the estimation of daily mean $\mathrm{N}_{2} \mathrm{O}$ flux from soils. Soil Biol Biochem 46:129-35.

Apolinário VX, Dubeux JC, Mello AC, Vendramini J, Lira MA, Santos MV, Muir JP. 2014. Litter decomposition of signalgrass grazed with stocking rates and nitrogen fertilizer levels. Agron J 106:622-7.

Barbero RP, Malheiros EB, Araujo TLR, Nave RLG, Mulliniks JT, Berchielli TT, Ruggieri AC, Reis RA. 2015. Combining Marandu grass grazing height and supplementation level to optimize growth and productivity of yearling bull. Anim Feed Sci Technol 209:110-18.

Blicher-Mathiesen G, Hoffmann CC. 1999. Denitrification as a sink for dissolved nitrous oxide in a freshwater riparian fen. $\mathrm{J}$ Environ Qual 28:257-62.

Boddey RM, Macedo R, Tarré RM, Ferreira E, de Oliveira OC, Rezende CP, Cantarutti RB, Pereira JM, Alves BJR, Urquiaga S. 2004. Nitrogen cycling in Brachiaria pastures: The key to understanding the process of pasture decline. Agric Ecosyst Environ 103:389-403.

Bremer DJ, Ham JM, Owensby CE, Knapp AK. 1998. Responses of soil respiration to clipping and grazing in a tallgrass prairie. J Environ Qual 27:1539-48.

Brito LF, Azenha MV, Janusckiewicz ER, Cardoso AS, Morgado ES, Malheiro EB, La Scala Jr N, Reis RA, Ruggieri AC. 2015. Agron J 107(957):962.
Cao GM, Tang YH, Mo WH, Wang YA, Li YN, Zhao XQ. 2004. Grazing intensity alters soil respiration in an alpine meadow on the Tibetan plateau. Soil Biol Biochem 36:237-43.

Cardoso AS, Alves BJR, Urquiaga S, Boddey RM. 2016. Effect of volume of urine and mas of feces on $\mathrm{N}_{2} \mathrm{O}$ and $\mathrm{CH}_{4}$ emissions of dairy cow excreta in a tropical pasture. Anim Product Sci. doi:10.1071/AN15392.

Chamberlain SD, Boughton EH, Sparks JP. 2015. Underlying ecosystem emissions exceed cattle-emitted methane from subtropical lowland pastures. Ecosystems 18:933-45.

Carter MS, Larsen KS, Emmett B, Estiarte M, Field C, Leith ID, Lund $M$, Meijide A, Mills RTE, Niinemets Ü, Peñuelas J, Portillo-Estrada M, Schmidt IK, Selsted MB, Sheppard LJ, Sowerby A, Tietema A, Beier C. 2012. Synthesizing greenhouse gas fluxes across nine European peatlands and shrublands-responses to climatic and environmental changes. Biogeosciences 9:3739-55.

Chen WW, Wolf B, Zheng XH, Yao ZS, Butterbach-Bahl K, Bruggemann N, Liu CY, Han SH, Han XG. 2011. Annual methane uptake by temperate semiarid steppes as regulated by stocking rates, aboveground plant biomass and topsoil air permeability. Glob Change Biol 17:2803-16.

Chiavegato MB, Powers WJ, Carmichael D, Rowntree JE. 2015. Pasture-derived greenhouse gas emissions in cow-calf production systems. J Anim Sci 93(1350):54.

Chapuis-Lardy L, Wrage N, Metay A, Chotte JL, Bernoux M. 2007. Soils, a sink for $\mathrm{N}_{2} \mathrm{O}$ ? A review. Glob Change Biol 13:117.

de Pinho Costa KA, Rosa B, de Oliveira IP, Custódio DP, Carla D. 2006. Efeito da estacionalidade na produção de matéria seca e composição bromatológica da Brachiaria brizantha cv. Marandu. Ciência Animal Brasileira 6:187-93.

Dengel S, Levy PE, Grace J, Jones SK, Skiba UM. 2011 . Methane emissions from sheep pasture, measured with an open-path eddy covariance system. Glob Change Biol 17:3524-33.

Dobbie KE, McTaggart IP, Smith KA. 1999. Nitrous oxide emission from intensive agricultural systems: variations between crops and seasons, key driving variables, and mean emission factors. J Geophys Resour 104:26891-9.

Euclides VPB, Montagner DB, Barbosa RA, Nantes NN. 2014. Pasture and grazing management of Brachiaria brizantha (Hochst) Stapf and Panicum maximum Jacq. Revista Ceres 61:808-18.

FCAV. 2014. Resenha meteorológica do período 1971-2010. Average meteorological data from agrometeorological station of Faculdade de Ciência Agrária de Jaboticabal, São Paulo, Brazil. Avaliable in: http://www.fcav.unesp.br/\#!/estacaoagroclimatologica/resenha/periodo-1971-2010/

Gong YM, Mohammat A, Liu XJ, Li KH, Christie P, Fang F, Song W, Chang YH, Han WX, Lü XT, Liu YY, Hu YK. 2014. Response of carbon dioxide emissions to sheep grazing and $\mathrm{N}$ application in an alpine grassland-Part 1: Effect of sheep grazing. Biogeosciences 11:1743-50.

Gusmao MR, Alves TC, Lemes AP, Bettiol GM, Pedroso ADF, Barioni Junior W, Oliveira PPA, Grego CR. 2015. Sodium fluorescein as an internal tracer on the location of bovine urine patches in pastures. Grass Forage Science 71:305-14.

Haynes RJ, Williams PH. 1993. Nutrient cycling and soil fertility in the grazed pasture ecosystem. Adv Agron 49:119-99.

Holter P. 1997. Methane emissions from Danish cattle dung pats in the field. Soil Biol Biochem 29:31-7. 
Hu YG, Chang XF, Lin XW, Wang WF, Wang SP, Duan JC, Zhang ZH, Yang XX, Luo CY, Xu GP, Zhao XQ. 2010. Effects of warming and grazing on $\mathrm{N}_{2} \mathrm{O}$ fluxes in an alpine meadow ecosystem on the Tibetan plateau. Soil Biol Biochem 42:94452.

IUSS. 2006. World reference base for soil resources 2006. FAO, Rome, Italy: World Soil Resources Reports.

Kelly KB, Phillips FA, Baigent R. 2008. Impact of dicyandiamide application on nitrous oxide emissions from urine patches in northern Victoria, Australia. Aust J Exp Agric 48:156-9.

Kempers AJ, Zweers A. 1986. Ammonium determination in soil extracts by the salicylate method. Commun Soil Sci Plant Anal $17: 715-23$.

Klumpp K, Bloor JMG, Ambus P, Soussana JF. 2011. Effects of clover density on $\mathrm{N}_{2} \mathrm{O}$ emissions and plant-soil $\mathrm{N}$ transfers in a fertilized upland pasture. Plant Soil 343:97-107.

Laporte MF, Duchesne LC, Wetzel S. 2002. Effect of rainfall patterns on soil surface $\mathrm{CO}_{2}$ efflux, soil moisture, soil temperature and plant growth in a grassland ecosystem of northern Ontario, Canada: implications for climate change. BMC Ecol 2:10.

Le Mer J, Roger P. 2001. Production, oxidation, emission and consumption of methane by soils: a review. Eur J Soil Biol $37: 25-50$.

Lessa ACR, Madari BE, Paredes DS, Boddey RM, Urquiaga S, Jantalia CP, Alves BJR. 2014. Bovine urine and dung deposited on Brazilian savannah pastures contribute differently to direct and indirect soil nitrous oxide emissions. Agric Ecosyst Environ 103:190-4.

Liebig MA, Kronberg SL, Hendrickson JR, Dong X, Gross JR. 2013. Carbon dioxide efflux from long-term grazing management systems in a semiarid region. Agric Ecosyst Environ 164:137-44.

Liu K, Sollenberger LE, Silveira ML, Vendramini JMB, Newman YC. 2011. Grazing intensity and nitrogen fertilization affect litter responses in 'Tifton 85 ' bermudagrass pastures. II. Decomposition and nitrogen mineralization. Agron J 103:163-8.

Liu CY, Holst J, Bruggemann N, Butterbach-Bahl K, Yao ZS, Yue J, Han SH, Han X, Krummelbein J, Horn R, Zheng XH. 2007. Winter-grazing reduces methane uptake by soils of a typical semi-arid steppe in Inner Mongolia, China. Atmos Environ 41:5948-58.

Luo J, Lindsey SB, Ledgard SF. 2008. Nitrous oxide emissions from animal urine application on a New Zealand pasture. Biology Fertility Soils 44:464-70.

Lopes AS. 1996. Soils under Cerrado: a success story in soil management. Better Crops Int 10:9-15.

Miranda EM, Fonseca MF. 2013. Considerações fitogeográficas e históricas sobre o bioma cerrado no estado de São Paulo. Embrapa Grupo de Inteligência Territorial nota técnica 1:1-30. https://www.embrapa.br/gite/publicacoes/NTl_CERRADOS_ 2013.pdf

Mott GO, Lucas HL. 1952. The design, conduct and interpretation of grazing trials on cultivated and improved pastures. In: Proceedings of the Sixth International Grassland Congress, Pennsylvania, pp. 1380-1385.

Mazzetto AM, Barneze AS, Feigl BJ, Van Groenigen JW, Oenema O, Cerri CC. 2014. Temperature and moisture affect methane and nitrous oxide emission from bovine manure patches in tropical conditions. Soil Biol Biochem 76:242-8.
Miyazawa M, Pavan MA, Block MFM. 1985. Spectrophotometry determination of nitrate in soil extracts without chemical reduction. Pesquisa Agropecuária Brasileira 20:29-133.

Mosier AR. 1989. Chamber and isotope techniques. In: Andreae MO, Schimel DS, Eds. Exchange of traces gases between terrestrial ecosystems and the atmosphere: report of the dahlem workshop. Germany: Wiley. p 175-87.

Olsen KK. 2008. Multiple wavelength ultraviolet determinations of nitrate concentration, method comparisons from the preakness brook monitoring project, October 2005 to October 2006. Water Air Soil Pollution 187:195-202.

R Core Team (2014). R: A language and environment for statistical computing. R Foundation for Statistical Computing, Vienna, Austria. https://www.R-project.org/.

Rochette P, Chantigny MH, Ziadi N, Angers DA, Bélanger G, Charbonneau E, Pellerin D, Liang C, Berthand N. 2014. Soil Nitrous Oxide emissions after deposition of dairy cow excreta in Eastern Canada. J Environ Qual 43:829-41.

Roslev P, King GM. 1994. Survival and recovery of methanotrophic bacteria starved under oxic and anoxic conditions. Appl Environ Microbiol 61:1563-70.

Saggar S, Hedley CB, Giltrap DL, Lambie SM. 2007. Measured and modelled estimates of nitrous oxide emission and methane consumption from a sheep-grazed pasture. Agric Ecosyst Environ 122:357-65.

Saggar S, Bolan N, Bhandral R, Hedley M, Luo J. 2004. A review of emissions of methane, ammonia, and nitrous oxide from animal excreta deposition and farm effluent application in grazed pastures. N Z J Agric Res 47:513-44.

Schlesinger WH. 2013. An estimate of the global sink for nitrous oxide in soils. Glob Change Biol 19:2329-931.

Shariff AR, Biondini ME, Grygiel CE. 1994. Grazing intensity effects on litter decomposition and soil nitrogen mineralization. J Rangel Manag 47:444-9.

Skiba U, Ball B. 2002. The effect of soil texture and soil drainage on emissions of nitric oxide and nitrous oxide. Soil Use Manag 18:56-60

Smith KA, Ball T, Conen F, Dobbie KE, Massheder J, Rey A. 2003. Exchange of greenhouse gases between soil and atmosphere: interactions of soil physical factors and biological processes. Eur J Soil Sci 54:779-91.

Sordi A, Dieckow J, Bayer C, Albuquerque MA, Piva JT, Zanatta JA, Tomazi M, da Rosa C, de Moraes A. 2013. Nitrous oxide emission factors for urine and dung patches in a subtropical Brazilian pastureland. Agric Ecosyst Environ 190:94-103.

Sorrell BK, Boon PI. 1992. Biogeochemistry of billabong sediments. II. Seasonal variations in methane production. Freshw Biol 27:829-37.

Steinfeld H, Gerber P, Wassenaar T, Castel V, Rosales M, Haan CD. 2006. Livestock's long shadow: environmental issues and options. Food and Agriculture Organization of the United Nations (FAO).

Thomas AD, Dougill AJ, Elliott DR, Mairs H. 2014. Seasonal differences in soil $\mathrm{CO}_{2}$ efflux and carbon storage in Ntwetwe Pan, Makgadikgadi Basin, Botswana. Geoderma 219-220:72-81.

Thomas AD, Hoon SR. 2010. Simulated rainfall pulses and carbon dioxide fluxes from Kalahari Sands. J Arid Environ 74:131-9.

Van der Weerden TJ, Luo J, Klein CAM, Hoogendoorn CJ, Littlejohn RP, Rys GJ. 2011. Disaggregating nitrous oxide emis- 
sion factors for ruminant urine and dung deposited onto pastoral soils. Agric Ecosyst Environ 141:426-36.

Van Groenigen JW, Velthof GL, van der Bolt FJE, Vos A, Kuikman PJ. 2005. Seasonal variation in $\mathrm{N}_{2} \mathrm{O}$ emissions from urine patches: effect of urine concentration, soil compaction and dung. Plant Soil 273:15-27.

Wang ZW, Jiao SY, Han GD, Zhao M, Willms WD. 2009. Soil respiration response to different stocking rates on Stipa breviflora Griseb. Desert Steppe. J Inner Mongolia Univ 40:186-93.

Wohlfahrt G, Hammerle A, Haslwanter A, Bahn M, Tappeiner U, Cernusca A. 2008. Seasonal and inter-annual variability of the net ecosystem $\mathrm{CO} 2$ exchange of a temperate mountain grassland: Effects of weather and management. J Geophys Res 113:D08110.

$\mathrm{Xu}$ L, Baldocchi DD. 2004. Seasonal variation in carbon dioxide exchange over a Mediterranean annual grassland in California. Agric For Meteorol 123:79-96.

Zaman M, Nguyen ML. 2012. How application timings of urease and nitrification inhibitors on $\mathrm{N}$ transformation, gaseous emissions of ammonia and nitrous oxide, pasture yield and $\mathrm{N}$ uptake in grazed pasture system. Soil Biol Biochem 41:127080.

Zhang LH, Hou LY, Laanbroek HJ, Guo DF, Wang QB. 2015. Effects of Mowing Heights on $\mathrm{N}_{2} \mathrm{O}$ Emission from Temperate Grasslands in Inner Mongolia, Northern China. Am J Climate Change 4:397-407.

Zhou X, Wang J, Hao Y, Wang Y. 2010. Intermediate grazing intensities by sheep increase soil bacterial diversities in an Inner Mongolian steppe. Biol Fertil Soils 46:817-24.

Zhu X, Luo C, Wang S, Zhang Z, Shujuar C, Bao X, Jiang L, Li Y, Li X, Wang Q, Zhou Y. 2015. Effects of warming, grazing/cutting and nitrogen fertilization on greenhouse gas fluxes during growing season in an alpine meadow on the Tibetan Plateau. Agric For Meteorol 214-215:506-14.

Zou J, Huang Y, Sun W, Zheng X, Wang Y. 2005. Contribution of plants to $\mathrm{N}_{2} \mathrm{O}$ emissions in soil-winter wheat ecosystem: pot and field experiments. Plant Soil 269:205-11. 